\title{
RUSSIAN FAMILY LAW LEGISLATION: REVOLUTION, COUNTER-REVOLUTION, EVOLUTION
}

\author{
NADEZHDA TARUSINA, \\ Demidov Yaroslavl State University (Yaroslavl, Russia) \\ ELENA ISAEVA, \\ Demidov Yaroslavl State University (Yaroslavl, Russia)
}

DOI: 10.21684/2412-2343-2017-4-4-65-92

This article analyzes the political and legal aspects of the first decrees of the Soviet government from 1917 and the codified acts on marriage and family from 1918 and 1926 as large and small "revolutions" in Russian and Soviet family law. These acts put Russia forward into progressive positions in comparison with comparable European and American law of that time. The article analyzes the repressive, "counterrevolutionary" decisions of 1930s and 1940s that pushed family law, particularly in the sphere of marriage and the legal status of children born out of wedlock, back to pre-revolutionary imperial standards. It also reviews the normative legal acts on marriage and the family dating from the "Khrushchev thaw" period. The article identifies the contradictory and conflicting approaches of legal scholars and legislators to the methodology of legal regulation of family relations in different periods of political and social history, as well as in our times. The quality of Russia's current family legislation, which mainly evolved during the political, economic and social reforms of the late $20^{\text {th }}$ century, is also assessed. The article traces the influence of Soviet family law on the content of similar legislation elsewhere in Eastern Europe and the countries of the former Soviet Union, where there are various levels of legal sovereignty. Their independent legal positions, which are worth comparing with Russia's family-law doctrine and legislation, are revealed. The article investigates and evaluates both successful and partially unsuccessful attempts of modern Russian legislators to adapt the current Family Code and other federal laws regulating family relations to new challenges in the sphere of marriage and family. It speculates on three tendencies of family law doctrine: a certain adherence to the revolutionary ideas of 1917, an orientation toward a return to traditional family values, and a relatively peaceful coexistence with Western doctrines.

Keywords: revolution; counter-revolution; decrees; marriage and family; codes of laws; doctrine; history; influence; contemporary challenges. 
Recommended citation: Nadezhda Tarusina \& Elena Isaeva, Russian Family Law Legislation: Revolution, Counter-Revolution, Evolution, 4(4) BRICS Law Journal 65-92 (2017).

\section{Table of Contents}

\section{Introduction}

\section{Legislation on Marriage and Family: A Revolutionary Breakthrough}

2. The Legislation of the 1940s: Up the Down Escalator, or Counter-Revolution 3. Reform: Evolution, Regress; Critics and Forecasts

\section{Conclusion}

\section{Introduction}

One side effect of the 1917 Revolution was the emergence of a new branch of Russian legislation - a vivid, if unexpected outcome of revolutionary ideas and practices. Almost premature, it arose far earlier than could have been anticipated, built on highly complicated, non-obvious ties to a legal framework, almost fully destroyed by the revolution.

However, like any other public phenomenon, this new legislation came out of the thoughts, intentions and actions of proponents of a civil doctrine, who sought to find a role for marriage and family legislation within Russian law in general, as well as the ideas of critics of the application of legal processes to the domestic sphere and even, to a significantly lesser extent, of legislators themselves. Thus, although these legal provisions seemed to be clearly present in civil and church law, by the late $19^{\text {th }}$ and early $20^{\text {th }}$ century, there were increasing doubts that these standards were that obvious.

Firstly, many civil lawyers emphasized the limited nature of the law in regulating family relations and its limited impact on marriage and family institutions, where the biological and moral rules were vastly more influential.' Some civilians also pointed out the somewhat alien nature of these institutions with respect to civil law in its classical sense. They stressed that, outside of property legislation, the nature and purpose of family legislative norms are alien to civil law, while the state's and the public's interest in healthy marriages and families rather demonstrate that these norms should be part of a state or church law system (D. Meyer). Relying on his own legal practice and comparing the classical civil relations and family relations, A. Borovikovsky referred to his own legal practice when he compared classical civil 
relations and family relations, pointing out the "mysterious" nature of the latter. He saw parallels between a family and a "living organism" that cannot clearly be defined as animal or vegetable.

Whether a debtor and a creditor like each other, - continued the author,is an idle question. One debtor pays his debt willingly, the other pays and curses his creditor, but both cases are legally the same... However, it is far from idle to question whether a wife and a husband are well-disposed towards each other, for here love is the very essence of the relationship... ${ }^{2}$

Anticipating the doctrine and lawmaking of the $20^{\text {th }}$ century, the same author expressed the idea that family matters require completely different procedures and forms of justice, distinct from the way standard civil law cases are investigated, and the wrote of the expediency of creating dedicated family courts. ${ }^{3}$

Of course, there were other, more traditional opinions, which reflected the actual state of Russian imperial legislation. Thus, for instance, one of the most famous civil lawyers of the early $20^{\text {th }}$ century, $G$. Shershenevich, based on traditions of private law, had no doubts about designating the property and personal aspects of family law to civil law, and the norms of marriage and divorce as a component of church law. At the same time, the author emphasized that where legal and ethical norms coincide, the former appear to be superfluous. However, he argued, where they are in opposition, then the conflict is unequal because "family relations are isolated, psychologically elusive": "the right to mutual love, respect, reverence" should not be attributed to family rights "because these are alleged rights deprived of any sanctions."

However, when describing the manifestations of a husband's and father's personal power $\mathrm{G}$. Shershenevich could not avoid the legal implications of nonlegal wordings:

Marriage imposes upon spouses a duty of faithfulness... The moral communication established by marriage limits the possibility of testimony in court... Children are obliged to respect. ${ }^{4}$

Legislative activities of the late $19^{\text {th }}$ and early $20^{\text {th }}$ centuries aimed to facilitate the divorce process and enhance the legal status of bastard children. Moreover, some representatives of the Orthodox clergy even came up with an idea to transfer some

2 Боровиковский А.Л. Отчет судьи [Alexander L. Borovikovsky, Report of the Judge] 212, 214 ( $2^{\text {nd }}$ ed., St. Petersburg: Tip. A.S. Suvorina, 1892).

Id.

Шершеневич Г.Ф. Учебник русского гражданского права [Gabriel F. Shershenevich, Manual of Russian Civil Law] 583-584, 618, 627 (Kazan: Knizhnyj magazin Brat'ev Bashmakovykh, 1905). 
aspects of marital law to secular legislation. However, the abortive 1905 Revolution, the World War I and the 1917 Revolution prevented these processes from reaching their logical conclusive. At the same time, it is notable that, despite growing public recognition of gender equality, this concept was not introduced into draft legislation. The husband and father enjoyed a seemingly unshakeable position as the institution of familial power.

At the same time, it should be noted that since the $18^{\text {th }}$ century, Russian civil legislation still contained some elements of gender equalization. Thus, the status of women in the Russian family traditionally allowed relatively broad rights: to own personal property and real estate (marriage did not invoke tenancy in full), to inherit ancestral territories where there were no heirs in the male line (a right not found in the law of European countries), to be a guardian (especially in case of widowhood), to possess a dowry and have rights to a fixed part of an inheritance. ${ }^{5}$

The idea of any significant change in approaches to the legal regulation of family relations was thus very much on the back burner for the political and legal minds of the early $20^{\text {th }}$ century. The country was entering 1917 , a year of two revolutions. However, from February to December 1917, the revolutionary authorities made no attempt to radically change family legislation: the liberal revolution, fueled by liberal political discussions, was interested in ideas of gender equality and a fair legal status for all children, regardless of the circumstances of their birth, but this did not translate into any concrete legislative activities.

\section{Legislation on Marriage and Family: A Revolutionary Breakthrough}

However one regards the historical events of October 1917 and irrespective of whether they are described as "the (Great) socialist revolution," "the October upheaval" or "anarchy," it is an obvious historical fact that this was a time of a supersignificant and super-progressive transformation of the legal status of relations affecting family life: marriage, parenthood and childhood. As noted above, there was a gradual but definite preparation of this ground in the political and civil law doctrines of the $19^{\text {th }}$ century and by very "cautious" legislative projects imperial Russia. However, the glacial progress of similar legislation across Europe suggests that it would have taken decades for a strategic, principled transition to be complete. The transformation demanded a departure from the classical approach to marriage with its relative (in some periods almost absolute) subordination of the wife and total subordination of children to the family, and discrimination of the legal status

See, e.g., Лушников А.М., Лушникова М.В., Тарусина Н.Н. Гендер в законе [Andrey M. Lushnikov et al., Gender in Law] (Moscow: Prospekt, 2015). Some historians and civil law specialists explain this with reference to the Russian empresses, for whom women's interests were "close to their heart." Meyer 1997 , at 364-365. 
of bastard children, to equal opportunities for spouses and children. The political "spark" had been missing - but now, suddenly, the tinderbox was struck.

As a result, marriage in the eyes of the church was abolished in favor of the secular form, many restrictions on marriage were lifted (e.g. in-law relations or spiritual affinity, maximum marital age, etc.), the principle of voluntary marriage and certain elements of equality were declared (including the right to choose the family name, place of residence and occupation), free legal recognition of bastard children was allowed and their full legal capacity, regardless of the circumstances of their birth, was declared (Decree of the Central Executive Committee and the Council of People's Commissars of 18(31) December 1917"On Civil Marriage, Children and Introduction of Civil Registers of Births, Marriages and Burials"). At the same time, the anti-church vector of the new marriage procedure did not categorically reject religious feelings (at that stage, without reference to circumstances, people of faith could still supplement the act of registering their marriage in registrar offices with a church ceremony and voluntarily observe religious conditions and restrictions, as long as they were optional and did not run counter to legal prohibitions). However, the general antireligious tendency was quite obvious, and soon brought its inevitable consequences: the positive revolutionary tendency consisted in separating the church from the state, paving the way for possible future excesses of condemnation and persecution of religious people.

Three days earlier, free judicial divorce was introduced - upon an application from one or both spouses. It was now possible to conclude an amicable agreement on children (their place of residence and alimony) and the need for judicial reflection on material support of the former spouse ("the judge determines... whether and in what amount the husband is obliged to provide food and maintenance to his divorced wife"). Of course, the decision on freedom of divorce made prior to the decision on freedom of marriage was quite logical, even if the order of events (first setting forth a decree on the termination of marriage and only then announcing a decree on establishing a marriage in the first place) was illogical. As for introduction of a liberal order to terminate unequal - and sometimes semi-coercive or forced marriages, this was timely and in line with revolutionary ideals.

In this regard, it is impossible to resist quoting the widely-known words of the leader of the October Revolution:

We did tear to shreds those vile laws on the inequality of women, - wrote Lenin, - on the constraints of divorce and the vile formalities around it, on the non-recognition of bastard children, on the search for their fathers, etc. - those laws, whose remnants are numerous in all civilized countries, to the shame of capitalism and the bourgeoisie. A thousand times over, we have the right to proud of what we have done in this respect. But the more we sweep the ground clean of the old, bourgeois laws and institutions, the 
clearer it becomes for us that this is only the levelling of the land for future construction, but yet not the construction itself. ${ }^{6}$

While the activities of this Russian politician can certainly be debated from all sides, the quoted statement seems to reflect the essence of the changes affecting the issue in question.

At the same time, political and social thought revolved around the future of family and its role in the life of a child, and several new ideas were planted in society: the "nationalization" of children; freedom from marriage; the abolition of individual alimony in favor of a state fund where individual alimony payments are collected and distributed equally among distressed children; transition to the prioritization of state support for family members (A. Kollontai). A draft of the Declaration of the Rights of the Child was proposed by K. Wentzel in 1918, and its status was assumed to be accepted at the international level. Many family law experts note that its content make it a prototype of the current UN Convention on the Rights of the Child (1989), as the draft contains ideas about a child's right to an acceptable level of life and free development of talents together with the provision of necessary living conditions; taking account of the child's own opinion on vital issues; the right to association; and the idea of imposing appropriate care for a child upon the parents, society and the state.' The draft was not formalized in the proposed version, but its provisions or similar ideas have been gradually introduced into family legislation as well as other sector-specific legislation.

Early decrees on marriage and family were followed by the Code of Acts on Civil Status, Marriage, Family and Guardianship Law (1918), the first codified normative legal act concerning marriage and family life. Family law now became systemized and turned into a sovereign branch of Russian legislation (in contrast with the situation across Europe, where the family was subordinated to the methodology of classic civil law and treated as one of its institutions). One modern-day school of civil thought contends that this was due to extenuating circumstances rather than a conscious decision: in the era of War Communism, civil law was regarded as dead and irrelevant. No one was going to revive it, but family relations still required an updated legal framework. Therefore, the gap left by the absence of civil law was filled by family law in the form of a separate Code. ${ }^{8}$ Without analyzing too deeply the role of circumstance in the history of doctrine and legislation, we must still emphasize that these circumstances contributed to the very rapid development of both. The sovereignty of family law as a branch has been repeatedly questioned

6 Ленин В.И. Полное собрание сочинений. Т. 39 [Vladimir I. Lenin, Complete Edition. Vol. 39] 23 (Moscow: Politizdat, 1970).

Id.

8 See, e.g., Антокольская M.B. Семейное право: Учебник [Mariya V. Antokolskaya, Family Law] 64 (Moscow: Yurist, 1997). 
and challenged with varying degrees of fervor and success, none of which rules out further discussion of several conflicting experiments in this sphere.

The 1918 Code reinforced the ideas put forward in the decrees. Furthermore, a provision was laid down on separation of marital property as a guarantee of the woman's freedom in marriage (at least, this was confidently expected at the time). Revolutionary experiments continued when Codes of Laws on marriage, family and custodial law were adopted in 1926. In particular, judicial practice points to a different approach to the division of property. Since the wife, traditionally, played the leading domestic role and was often not engaged in paid work outside the home (fulfilling the role of housewife, and not working for a living), a working husband would obviously hold a big advantage in the event of a divorce. The second Code recognized the legal significance of a woman's domestic responsibilities, based on a principle of joint ownership. Thus one revolutionary impulse was replaced by another, leading, unusually, to a fairer new interpretation. In the end, legislators were clearly guided by a spirit of reform when introducing norms about the legal recognition of de facto marriages. The legal consequences implied that property was held jointly, and alimony obligations were assessed just as they would be between legally-registered spouses (Arts. 11, 12 and 16). At this time, though, the doctrine and political trends of the day assumed that state registration of marriage would only be a temporary phenomenon, playing a short-term part in removing the church's role in regulating marriages. In future, a couple joined in matrimony but free from "legal shackles," would be the dominant feature of family life, a prototype for an equitable communist social institution. 'It is also noteworthy that the adoption of the Code was preceded by a broad public debate on all key issues. In particular, totally opposite points of view were expressed in regard to the legal recognition of a de facto marriage. Opponents argued that it would be hard to distinguish between a casual affair and something that qualifies as a stable family relationship, equivalent to a registered marriage. But those who advocated protection for the interests of de facto spouses insisted that this argument was self-resolving: the stable nature of a family relationship should be the criterion for distinguishing between long-term and casual attachments, and the professional discretion of the courts could be relied upon in each individual case. This proved to be the only open - and, by the standards of the time, completely liberal - discussion of the issue; subsequent decades saw no more free public debates until the so-called "thaw" of the early 1960s.

Leaving aside a few details, and regardless of the revolutionary fantasies of political and public figures, all the legal positions discussed above represented a genuine systemic breakthrough into a fundamentally new legislation on marriage and the family of the $20^{\text {th }}$ century. It had no equivalent in any institutions in Europe, far less in the USA. It would be several decades before Western countries were able

9 See, e.g., Тарусина Н.Н. Брак по российскому семейному праву [Nadezhda N. Tarusina, Marriage in Russian Family Law] 46-47, 145-146 (Moscow: Prospekt, 2010). 
to enact, to varying degrees, the ideas of freedom of marriage and divorce, equal rights for men and women, and equal treatment of all children, regardless of the circumstances of their birth.

\section{The Legislation of the 1940s: Up the Down Escalator, or Counter-Revolution}

The revolutionary-progressive spirit in the family legislation of 1917-1926 was extinguished by a peculiar, inflexible counter-revolution in this sphere in 1944. This change in attitudes was anticipated in 1936, which saw a tendency to emphasize the public principle in the legal regulation of private, family relations: in 1936, a proportional alimony system was introduced, which, as stated by M. Antokolskaya, was a "unified approach towards the conditions of universal equality in poverty"; ${ }^{\prime 10}$ this system, however, also played a positive role in making it easier to recover alimony. In the same year, abortion was criminalized. The well-known Russian feminist M. Arbatova wrote:

Russia introduced the new ban simultaneously with Nazi Germany. From 1936 to 1955 , thousands of doctors and women were convicted and shot for criminal abortions."

In increasingly reactionary times, on 8 July 1944, the Presidium of the Supreme Soviet of the USSR issued a Decree "On Increasing State Aid to Pregnant Women, Mothers with Many Children and Single Mothers, Strengthening Protection of Motherhood and Childhood, and Establishing the Honorary Title of Mother Heroine and the Establishment of the Mother's Glory Order and the Medal of Motherhood." A benevolent façade masked three "counter-revolutionary" decisions:

1) there was a strong refusal to recognize de facto marriage and its legal consequences (members of unregistered family unions were "invited" by the state to civil registration offices);

2) a "draconian" divorce procedure was introduced (preliminary publication in a newspaper, an obligatory stage of reconciliation in the district people's court, decision on the merits of the case in the regional/republican court, ${ }^{12}$ expensive fees in relation to wages). The procedure was often accompanied by public condemnation when individual cases were considered by party or trade union committee meetings;

10 Antokolskaya 2010, at 74.

11 Арбатова М. Феминизм, Известия, 19 февраля 1998 г., с. 5 [Maria Arbatova, Feminism, Izvestiya, 19 February 1998, at 5].

12 Given that many residential areas were isolated, accessible not by road but via unmarked tracks, a visit to a regional center to participate in a divorce hearing in a regional court would seem possible only for exceptional enthusiasts. 
3) illegitimate children were once again categorized, as neither voluntary recognition nor judicial determination of extra-marital paternity were permitted. Fathers would no longer be named on the child's birth certificate, ${ }^{13}$ there was only a "single mother," receiving a small state allowance. In these ways, the Decree set back our family legislation 100 years, adding a new chapter to the story in Orwellian style. That is how most civil law experts, with a greater or lesser degree of severity, evaluate its provisions on family law.

However, as is often the case, not all scholars agree with this verdict. While few deny the similarity of the pre-revolutionary imperial approach of canon law and the divorce decree, they insist that an outward similarity disguises fundamentally different motives: canon law sought to maintain a kind of "sexual discipline," ensuring the sanctity of marriage, while the decree wanted to rehabilitate marriage and strengthen family ties. It came partly as a response to the war, which prompted many extra-marital affairs and romances on the frontlines and back at home. This, in turn, saw a rise in the extramarital birth rate. The state wished to stabilize official marriages and, more importantly, free men from any obligations towards the mothers of any illegitimate children they may have fathered. That second aim, which provokes widespread indignation among scholars of family law, is overlooked by hardline supporters of the decree and related documents. These supporters hypocritically avoid any evaluation of the legislation in this context, reducing their position to a weak "voice in the wilderness" of dissent.

Some of this family legislation remained in force until 1965 (divorce procedures), others lasted until as late as 1968 (the status of illegitimate children). The legal implications of the state's refusal to recognize the legal consequences of a de facto marriage remain to this day. The latter circumstance will be further evaluated.

In 1968, the Fundamentals of Legislation of the USSR and the Union Republics on Marriage and Family were adopted, and 1969 brought the RSFSR Marriage and Family Code, which revived, to a certain extent, the ideas of the revolutionary years (except for legal protection of de facto matrimony, as noted above). However, there were still some restrictions concerning the status of illegitimate children with regards to freedom of judicial discretion in establishing paternity. Thus, the provision of Art. 48 of the Marriage and Family Code stipulated that when making a positive decision, courts could not assess every aspect of the family's life and must restrict themselves to considering one or more of the four issues below:

1) the cohabitation of the child's mother and prospective father;

2) their common household;

3) joint upbringing or maintenance of the child;

4) recognition of the child as their own.

13 According to apologists for the Decree, this measure should free men from any responsibility for the child's life and help resolve the demographic problem that inevitably arose during the war. Furthermore, society had partially reverted to disparaging extramarital motherhood, which, in fact, ran counter to the need for a sharp increase in the birth rate. 
In reality, public practice in this area was much more diverse and did not boil down to these criteria alone; there were instances (and more than a few) where paternity was evident to the court, but legislative restrictions made it impossible to make a positive decision. The "half-heartedness" of the legislator's position was a consequence of the influence of earlier, harsh decisions. However, this position was quite in line with trends in European family legislation of that time: after leading the way for decades after 1917, Russia escaped an "Orwellian space" only to join a wider circle of commonplace restrictions, albeit more liberal ones.

It should also be noted that the Code of 1969 substantially enforced the procedural principle, together with the procedural activity of the court - if not directly (Art. 34, etc.), then through its interpretation of the USSR's Supreme Court. The court's right to consider questions about custody of children and alimony arrangements ceased to be "recommended" and became "mandatory," regardless of the claims of the parties in divorce proceedings. This, however, was in line with the position of the Civil Procedure Code of the RSFSR of 1964, which expanded the grounds of judicial activities in civil proceedings. ${ }^{14}$

The 1969 Code served as a compromise between revolutionary fantasies about the freedom of marriage, family and parenthood that came from 1917-1918, and the "draconian" regulatory and legal decisions of the 1940s. It had some impact on family legislation across Eastern Europe: marriage and family standards were concentrated in a dedicated code, gender equality ideas were implemented, the property relations of spouses were based on joint ownership (without a marriage contract). Similarities could also be found among the institutions that established paternity and alimony obligations. At the same time, the legislation of these countries also had significant differences, conditioned both by the tendencies of their own doctrines of family law, and by the influence of Western European legislation. Thus, for instance, there was a deeper prohibition against marriage among kin, divorce was carried out exclusively via judicial proceedings (and guilt could be apportioned). In Hungary, the idea of an alimony fund was implemented; Russia then did the same for a time..$^{15}$ In the Family Code of Bulgaria there was no concept of an invalid marriage, ${ }^{16}$ and the Civil Procedure Code had a chapter on the specifics of considering family matters in court - this was absent and, to this day, non-existent in the relevant Russian law; the idea of an official starting point for civil proceedings, including the consideration

14 On the specifics of the Soviet and Russian civil procedure, see, e.g., Dmitry Maleshin, The Russian Style of Civil Procedure, 21(2) Emory International Law Review 545 (2007).

15 It should be recalled that for the first time, however, in a slightly different version (a"leveling out" through the state redistribution of private resources), a similar idea was expressed by the famous revolutionary and statesperson A. Kollontai in the post-revolutionary period of Russian family legislation.

16 Bulgarian civil lawyers by no means ignored the possibility that couple would not comply with the conditions necessary for a valid marriage, but they regarded them as grounds for "destroying"the marriage for the future - that is, they did not consider it necessary to apply the design of classical consequences of recognizing the deal as invalid (this approach remains effective in current legislation). 
of family cases, was not systemic (judicial activism), although components of this activism were originally introduced in the Civil Procedure Code of the RSFSR of 1964. While the USSR had timid doctrinal discussions about the idea of specialized family courts, a proposal voiced by Russian civil law scholars as early as the late 1800s, Poland was operating a dedicated (trusteeship) court. In countries like Bulgaria, Czechoslovakia and Romania, as part of the court process to dissolve a marriage, issues surrounding the parents' future access to their children and the use of the family home had to be considered as well. In Russia, these obligations only extended to questions of a child's home and the recovery of alimony. In other words, the Soviet impact on the family legislation of Eastern European countries was not unconditional and comprehensive, although, to a certain extent, it did set the tone when it was reformed after the war. There is a fairly obvious reason for this degree of relative sovereignty: the legal regulation of family relations was, as a rule, more actively derived from national and cultural traditions.

\section{Reform: Evolution, Regress; Critics and Forecasts}

The next wave of significant changes to family law came in 1994-1995, as a result of political, economic and other state and public reforms. This wave contained aspects of both revolutionary and counter-revolutionary energy. On the one hand, the new Family Code retained basic ideas of the institutions of marriage and parenthood and thus repeated the merits and shortcomings of the 1969 Code. On the other, it rejected some of the unique benefits of the earlier code and accepted ideas from Western doctrines of family law without criticism. As a result, Russia's current family legislation is self-contradictory and sits uncomfortably with related civil and civil-procedural law.

Let us look at this in more detail. The common principles of Russian family law remained almost unchanged. However, they reflected a tendency to converge with civil law: the provisions of Arts. 4 and 5 of the Family Code allow the latter to be applied as a subsidiary measure and by analogy. Article 8 , without listing the forms and methods of protecting family rights, directs us to the Civil Code by default. In this case, the Civil Code is by no means a universal source of information - there are significant differences in the scope of family law and civil law regulation. However, the idea of permitting civil law to place "ideological" pressure on family relations has become deeply rooted in the doctrine. Along with the St. Petersburg school of civil law (which traditionally doubted the sovereignty of family law), it was also picked up by some representatives of the Moscow school of private law (in the face of active resistance from classical scholars of family law).

Contrary to modern legislative requirements, the General Provisions contain neither definitions of basic concepts (marriage, family, guardianship, kinship, ${ }^{17}$

17 Despite announcing a program for the preservation of family values, the legislation lacks general and specific characteristics of kinship and property and offers a simple list of close relatives, with the term "other" to indicate any additional persons. 
property, etc.), nor features (specifics) and varieties of the concept of a family-legal contract, the scope of which is substantially expanded. In the former Soviet republics (currently, the CIS states), codified acts on marriage and the family are generally constructed in a different way. In particular, these contain definitions of the key concepts. Kazakhstan's Marriage and Family Law, for example, offers 18 definitions, including marriage, fictitious marriage and foster families, despite largely following Soviet-era and modern Russian legislation. ${ }^{18} \mathrm{Clearly}$, it is far from easy to bridge this gap. Moreover, civil doctrine in Russia and Europe alike is highly skeptical about attempts to define key concepts such as "marriage" or "family."19,20

However, this is the goal set before the legal expert community as part of designing changes to the general part of the Family Code. The likelihood of a successful solution depends equally on those experts and the legislators themselves, who, traditionally, have taken contradictory and unstable positions with regards to legal regulation of family relations.

There were two significant changes within the institution of marriage; both were taken from equivalent Western European doctrines and in both cases, as often happens during widespread changes in Russian society and the state, were implemented with gaps, deviations and flaws.

The first change affected divorce proceedings: along with administrative and judicial ways to dissolve the marriage, long part of traditional Russian family law, the concept of "divorce by mutual consent" was introduced. But, following the old tradition that assumed an inevitable conflict between family and civil procedural legislation, the amendment led to no changes in legal proceedings. There was no separation between litigation (where the law was disputed) and specialized proceedings to terminate marriage by mutual consent in cases where the spouses have common underage children and cannot terminate the marriage under the jurisdiction of the registry office. This can be partly justified by the court's duty to resolve questions about the child's place of residence and maintenance alongside the main claim of the divorce proceedings. Even so, a dedicated niche could have been found for this complicated procedural arrangement, if only to avoid a conflict of paradox (or a situation reduced to absurdity), where two parties who are in agreement over the main case must take part in adversarial proceeding, having to

18 See for details Nadezhda Tarusina, European Experience and National Traditions in Russian Family Law, 3(2) Russian Law Journal 97 (2015).

19 See, e.g., Jonathan Herring, Family Law 36-39 (3 ${ }^{\text {rd }}$ ed., New York: Pearson Longman, 2007).

20 The dispute in Great Britain's Parliament on the adoption of the Marriage (Same Sex Couples) Act 2013 is quite exemplary. There were two competing discourses of the purpose of marriage expressed in these debates in Parliament, both of which can be tied to a heteronormative understanding of the purpose and function of marriage: that marriage is either about "love" or "procreation." Analysis of this debate shows that those who spoke in favor of same-sex marriage primarily construed the purpose of marriage as "love," while those who opposed focused on the issue of "procreation."In her introduction of the Bill on behalf of the Government, Maria Miller, the minister for women and equalities, focused on love. After Legal Equality: Family, Sex, Kinship 187 (R. Leckey (ed.), Abingdon, Oxon; New York, NY: Routledge, 2015). 
agree on who is the plaintiff and who is the defendant (or, alternatively, apply jointly to the court for the termination of the marriage).

There was also no correction of the conflicting norms about the court's obligation above to resolve divorce-related issues (Art. 24 of the Family Code of the Russian Federation) and provisions of Art. 4 of the Civil Procedure Code of the Russian Federation, which does not envisage such initiative. Judicial practice has attempted to interpret this obligation as the right of a court to go beyond its stated requirements, but this is, to put it mildly, very creative. First, it proposes that an obligation be perceived as a right, and an imperative as a form of judicial discretion. Furthermore, as is known, if the court goes outside the specified limits, it needs to meet the assumptions of Art. 136 of the Civil Procedure Code of the Russian Federation; these limits are restricted by the substance of any disputable legal relationship (in this case, a marriage) - and no other legal relationship, though these may be connected. Since the legislator is preoccupied with the specific protection of children's interests and does not, therefore, intend to change the related rules of Art. 24 of the Family Code of the Russian Federation, he could resort to one of two options to remove the conflict. One choice would be to establish the court's ability to resolve the claim filed by the plaintiff and all related issues simultaneously, inasmuch as they protect significant public interests (in cases identified specifically in the legislation). This could be established in the norms of Art. 4 of the Civil Procedure Code of the Russian Federation. The other option would be to expand the comparable powers of the court as part of the rules of Art. 136 of the Civil Procedure Code of the Russian Federation, so that these powers would cease to be a discretionary right, but be an obligation to go beyond the stated claims. Unfortunately, though, Russia's legal system has no tradition of tying up loose ends before drafting new family and civil procedural legislation. ${ }^{21}$

The second change in the institution of marriage can be attributed to revolutionary (and, from a certain point of view, "counterrevolutionary") reforms: the framework of a marriage contract was unknown not only to the Soviet legal system only, but to Russian imperial legislation prior to 1917. This was an obvious and essential adoption from the European law, but it came with gaps and alterations. As a result, the subjects of a marriage contract can be spouses, but also some mysterious "persons entering into marriage" who can act as a prospective party to the agreement for an indefinite period before the marriage is formally concluded. The content of the marriage contract is limited to the issues of the spouses' property statuses, which reflects European trends and, of course, has its merits. ${ }^{22}$ At the same time, the marriage contract, contrary to

21 This conflict is not only limited to divorce processes: in cases of deprivation of parental rights and the abolition of adoption, the court uses its own initiative to make decisions about the recovery of alimony for the child from the defendants (item 4 of Art. 70, item 4 of Art. 143 of the Family Code of the Russian Federation). The only difference in these cases is the court's right, not its obligation.

22 E.g., family legislation in Belarus, which also adopted the concept of marriage contract, offers the idea of comprehensive content (of the Anglo-Saxon type) - with the assumption that personal legal issues including children, would form part of the agreement. 
its main purpose of determining the ownership of property held in marriage, can, according to Art. 40 of the Family Code of the Russian Federation, be concluded with mandatory notarization "one minute before the divorce," despite the fact that family law also provides arrangements for an agreement on the division of common spousal property. Finally, the provisions of Arts. 40 and 42 of the Family Code give spouses the right to determine their own agreements about property - including complete separation. This is intended to support the principles of justice and equality. However, it should be noted that the theory does not always happen in practice. Real gender equality in Russian families is by no means an established fact: as a rule, a working woman still keeps the household and cares for any children or other relatives, but the housework of a "non-working" woman has no official legal and economic assessment and is not declared socially useful. In addition, any agreement by which spouses hold their individual property separately needs to be combined with the intention of securing the family's common interests, including caring for any children. This axiom is underpinned by the principles of family legislation (Art. 1 of the Family Code of the Russian Federation). However, there are two issues. First, what prevented legislators from the outset - from enforcing this interest directly in the provisions of marriage contracts? Secondly, we cannot ignore the key fact that the tradition of spouses holding property in common evolved based on a relationship between three interest groups: the family as a whole, the socially weaker party in the marriage, and the children of the couple. The current level of freedom in marriage contracts, in fact, negates these guarantees. We also believe that, from a doctrinal standpoint, it is unacceptable to apply totally opposite methods to regulating the same type of family relations: it is common knowledge that the means must reflect the specifics of their desired ends; in the case of marriage and family relations, this assumption is almost axiomatic. ${ }^{23}$

Currently, the doctrine and the draft legislation on alimony for a spouse (former spouse) is clearly influenced by ideas derived from Western law: the system of offering material child care to a former spouse for up to three years was intended to become gender neutral and available to fathers as well as mothers; there are also plans to expand the grounds on which to claim alimony by framing them in a non-exhaustive fashion based on judicial discretion relating to the individual circumstances of the parties in a divorce.

Among the most contentious points concerning the institution of marriage are the lack of legal protections for couples in de facto marriages, or partnerships, and the refusal to allow same-sex couples any official right to marry. Although these are separate issues, they are interconnected.

23 Not without reason, in the civil doctrine there was a discussion about the nature of the marriage contract - whether it belongs to family or civil law. And, along with the development of contractual principles in family law, the idea evolved of the need for a dedicated institute of family-legal contracts which would reflect the specifics of family relations. For details, see Тарусина Н.Н., Лушников А.М., Лушникова М.B. Социальные договоры в праве [Nadezhda N. Tarusina et al., Social Contracts in Law] 65-71 (Moscow: Prospekt, 2017). 
As we have already noted, from 1926 to 1944 , Russian legislators allowed legal rights to marriages even without state registration. This, indeed, was intended as a prototype of communist marriage, the first step towards the complete removal of formal state control over family unions. In terms of upholding the authority of the state and the law was, of course, a fantasy, and any communist society was far away both then and now (even if, in principle, such a possibility can be entertained). At the same time, it should be noted that the practice of recognizing de facto marriage and protecting the socially weaker party in this union (usually the woman) was an unprecedented decision, several decades ahead of the respective legal positions of European countries.

Typically, it took Europe's legal systems another 50 years to offer legal recognition to unregistered partnerships (initially, heterosexual couples). By this time, legislators in the USSR and then Russia, had taken the opposition position, reversing their earlier assumptions. The last five years have brought a renewed discussion on this topic. In our opinion, just three years ago Russia came close to softening its stance and offering partial recognition of the legal consequences of unregistered de facto heterosexual marriage. This would have ensured fair protection of the interests of both parties in the relationship, including a framework of judicial discretion to give rulings in case of conflict. This idea has been actively promoted by some family experts, including the author of this work, for many years. The respective draft bill was prepared, only to be unexpectedly excluded from even preliminary consideration as ill-timed and unworkable. ${ }^{24}$ Once again, there was a groundswell of opinion behind the belief that a de facto partnership was akin to "fornication," and that the marriage traditions of Orthodoxy, Islam and other faiths - as well as the secular values of Russian society - should be encouraged as far as possible. There was also a fear of a further increase in the number of unregistered partnerships if they gained even partial legal recognition. Around this time, Russia's civil doctrine came up with a viewpoint that could cautiously and tactfully allow a legal framework for same-sex family unions. ${ }^{25}$ In its first stage, this was possible in the form of partnerships such as those that had been implemented into European and, later, American legislation. ${ }^{26}$

24 Another confirmation of the relative sovereignty of the family legislation in the former USSR republics is the provision of the Family Code of Ukraine of 2004: in the norm of Art. 16 the Ukrainian legislator recognizes the possibility of applying joint ownership to a de facto marriage, and in Art. 91 - the rights to alimony.

25 See, e.g., Masha Antokolskaia, Harmonisation of Family Law in Europe: A Historical Perspective: A Tale of Two Millennia 273-312 (Antwerp: Intersentia, 2006).

26 Denmark was the first country in the world to give legal recognition to same-sex couples, who could register as domestic partners from 1989. In the 1990s, various forms of civil unions were introduced in Norway (1993), Sweden (1995), Iceland (1996) and France (1999). Belgium offered limited rights to same-sex couples through registered partnerships from 1998 onwards. Pamela Duncan, A History of Same-Sex Unions in Europe, The Guardian, 24 January 2016 (Nov. 2, 2017), available at https://www. theguardian.com/news/datablog/2016/jan/24/a-history-of-same-sex-unions-in-europe. In 2004, 
This happened against a background trend to recognize and equalize the legal statuses of traditional informal marriages and de facto same-sex partnerships. ${ }^{27}$ The European Court of Human Rights has repeatedly emphasized that any decision on these issues is the prerogative of national legislation. At the same time, the Court appeals to countries to promote the principle of gender equality. ${ }^{28}$ This has already been implemented in 14 European countries - on 30 June the German parliament "joined the club" and voted in favor of allowing same-sex marriage, despite Chancellor Angela Merkel voting against the bill. Not all governments are supportive of the idea: some countries, including Hungary, Poland and Croatia, ${ }^{29}$ have voted against similar proposals.

Even though the debate about how to interpret gender equality in Russian marriages remains high on the agenda for Russian jurisprudence, it has nevertheless become an episodic issue. On several occasions, the Constitutional Court of the Russian Federation has repeatedly rejected claims that the provisions of Art. 12 of the Family Code violate the constitutional principle of gender equality by interpreting marriage solely as a union between a man and a woman. ${ }^{30}$ Meanwhile, the idea of comprehensive support for traditional family relationships is dominating public debate. There seem to be few reasons to anticipate a "revolutionary" (or, rather, "counter-revolutionary") breakthrough in the foreseeable future.

However, it should be emphasized that there are contradictions in the position held by Russia's legislators. Sex-change surgery has been possible for many years now. However, there has been no legislative reaction to this. While Russian law regards heterosexuality as the bedrock of marriage, nothing prevents one of the spouses in a heterosexual marriage undergoing sex-change surgery. As a result, it is possible for two men or two women to be married, based purely on their mutual

the Civil Partnership Act not only legalized the same-sex cohabitation in the UK but also granted the civil partners the right to adopt children. Nichola Gray \& Dominic Brazil, Blackstone's Guide to the Civil Partnership Act 20043 (Oxford: Oxford University Press, 2005). According to statistics, in 2011, 26,000 civil partnerships were registered in the UK. Jane Sendall, Family Law Handbook 85 (Oxford: Oxford University Press, 2011).

27 Paul Johnson, Marriage, Heteronormativity, and the European Court of Human Rights: A Reappraisal, 29(1) International Journal of Law, Policy and the Family 56, 58 (2015).

28 See, e.g., Schalk and Kopf v. Austria, Application No. 30141/04, Council of Europe: European Court of Human Rights, 24 June 2010; Oliari and Others v. Italy, Applications Nos. 18766/11 and 36030/11, Council of Europe: European Court of Human Rights, 21 July 2015.

29 The Referendum of 1 December 2013 in Croatia. From 1 January 2012, the Constitution of Hungary defines marriage as a union of a man and a woman.

30 See, e.g., Decision of 16 December 2006 No. 496-O on the complaint of E. Murzin. The Court pointed out that the idea of marriage as a union of a man and a woman corresponds to the biological nature of a human, the targeted purpose of such union and Russia's national and cultural traditions. The court also emphasized that provision of Art. 12 of the Convention for the Protection of Human Rights and Fundamental Freedoms expressly provides the opportunity for creating a family in accordance with national legislation. 
agreement. A bill that proposed legal consequences for marriages in the event of one partner changing gender was recently rejected. ${ }^{31}$

So far, there have been no fundamental "revolutionary" changes in laws concerned parenthood and childhood: legislative decisions have been limited to those of an evolutionary character. Nonetheless, judicial practice still creates a certain dissonance in this sphere. Despite the accepted principle of parental equality, many court verdicts are based on the provisions of the Declaration of the Rights of the Child of 1959, which recognizes the mother's priority right to immediate custody of a young child; on the other hand, cases where fathers' rights are actively protected have become more frequent.

One significant achievement was the introduction of a specialised chapter dedicated to the status of the child. Earlier, children, generally treated as a subject of family law, remained somewhat "invisible" in terms of their family and legal status. That status was traced exclusively through the prism of the parents'status; they were called upon to consider their children's opinions and act in their interests. This development is partially in line with the UN Convention on the Rights of the Child of 1989, which Russia also joined in 1990 - however, not in full. Thus, the provision of item 1 of Art. 54 of the Family Code of the Russian Federation, which opens the chapter on the status of underage children, is an attempt to define a "child": "a child is a person who has not reached the age of 18." In the framework of family and civil law, this is in fact possible - for example, when a minor gets married. Russian family legislation does not align (at least, not directly) with the preamble of the Convention on the protection of a child's interests - both before and after birth. It is commonly known, that this idea underlies a number of European legal systems at a constitutional or other legislative level (e.g. in Germany, Ireland, the Netherlands, Slovakia, the Czech Republic, etc.). In the Russian law, this idea is not directly secured, although the interests of an unborn child are indirectly protected by: additional labor rights for pregnant women; limited rights for a husband to divorce his pregnant wife and her right to alimony when the child is born; the right of an unborn child to inherit; liability for murdering a pregnant woman; restrictions on access to abortion, etc.

The content of Russia's norms on establishing the paternity of children does not exactly match contemporary European trends. There is an unprecedented order to the courts that they must be guided only by reliable evidence when positively establishing paternity. This begs an inevitable question: could a court be allowed to rely on unreliable evidence in other cases? Obviously not. The general rules of civil proceedings on the court to be guided by the principles of relevance, admissibility and reliability of evidence

31 This, of course, does not mean the termination of the corresponding attempts. Apparently, the rejected bill did not solve the problem correctly. While this problem is in fact difficult to resolve: the concept of mandatory divorce is unacceptable, as also unacceptable is the concept for its recognition as invalid, whose application presupposes that there were certain violations before concluding marriage, and not after the act in question. 
used by the court when evaluating a conflict situation and rendering a judgment in any civil case. To understand this odd position, it is necessary to look into history and, in particular, 1944 and the move away from the revolutionary ideals of 1917 that offered equal rights to all children, regardless of the circumstances of their birth. It is also partly explained by the curious obsession among many civil lawyers to prevent courts from establishing paternity at their own discretion. These lawyers believe that judicial freedom of this kind (which, by the way, is inevitable when applying situational norms or legal norms with definite content $)^{32}$ would encourage women's frivolous behavior. ${ }^{33}$ This approach indicates a latent gender imbalance ${ }_{1}^{34}$ which is still characteristic of the Russian society. It also reflects the enduring idea of bastard children as subjects of a different sort. The revolutionary legal positions of the Soviet government's first decrees, rejected by the legislation of the forties, have still not been fully restored to their fully progressive stance on the status of children and gender equality.

A child's right to know his/her parents is subject to serious challenges related to the use of reproductive treatments. The main collision arises between the child's right and the donor's right to anonymity after making genetic material available for medically-assisted reproduction. Not all lawyers are in favor of keeping donor details confidential and limiting the right of children to identify their biological parents. Critics build their doubts upon several grounds. First, the Convention on the Rights of the Child identifies the right to seek the truth - to know the parents "... as far as possible." Second, trends in Europe are eroding donor anonymity (the Netherlands and Sweden were the first nations to abolish the principle), even though Russia is far from guaranteed to follow Europe's lead. Third, information on the biological origins of the child may be medically important to diagnose any hereditary illnesses.

At the same time, European legislators acted in response to the demands of "testtube babies," now adults, who began searching for their biological parents, sometimes using specialized internet services - as well as their mothers, in some cases. In one case, a 15-year-old child received a sample of his own DNA, ran it through a genetic database and found two matches. By collating this with information earlier provided by his mother, the youngster successfully identified his biological father. In another case, a mother of a child born with the use of Assisted Reproductive Technology discovered symptoms of autism as the child was growing older; after identifying the donor, it became clear that his brothers and sisters had a similar condition. It appears there are circumstances where declassification can be desirable.

The implementation of any surrogate motherhood program causes conflicts and controversial judgements. Firstly, the norm stated in Art. 51, item 4, part 1 of the Family

32 See for details Aharon Barak, Judicial Discretion (New Haven: Yale University Press, 1989).

33 See on reasons to reject the protection of interests of de facto spouses discussed above.

34 See for details Nadezhda Tarusina \& Elena Isaeva, Equalization of Legal Status with Respect to Gender, 4(3) Russian Law Journal 74 (2016). 
Code of the Russian Federation has obviously become obsolete and contradicts with medical legislation: it assumes only married couples will take part in the program, whereas health legislation considers the involvement of couples ${ }^{35}$ and "single women."36 Only single men have no access to the program. As a result, some single men seek out surrogate motherhood programs in other countries, particularly the US. This gender discrimination has attracted criticism from family law experts but has not, so far, resulted in any adjustments to Russian family and medical legislation. The most significant collision arises from the provision stipulated in Art. 51, item 4, part 2 of the Family Code of the Russian Federation, which states that the genetic parents can only be registered as the child's parents with the consent of the surrogate mother. Priority therefore goes to the woman who physically carried and gave birth to the child. Since she could be married to a different man, who earlier consented to his wife's participation in the program, her husband becomes a de facto social father to the child.

The Constitutional Court of the Russian Federation has given an opinion on this issue. In the Decision of the Court of 15 May 2012 No. 880-0 "On Refusal to Accept the Complaint of Citizens of Ch.P. and C.Yu for the Violation of Constitutional Rights by the Provisions of Item 4 of Article 51 of the Family Code of the Russian Federation and Item 5 of Article 16 of the Federal Law'On Civil Status Acts"' there is no contradiction to constitutional norms. However, within these legal proceedings, two dissenting opinions were expressed. The judge $S$. Knyazev emphasized that the legislator, while fixing the prerogative of the surrogate mother in resolving the issue of allotting the genetic parents and their corresponding rights and duties, does not take into account those same rights and interests in respect of the people who provide the sex cells that are used for fertilization. As a result, the interests of the child are not taken into account (including the right to be brought up in a full family, which is not always possible with a surrogate mother). The bearing and birth of a child by a surrogate mother cannot, on their own, give her unlimited freedom to determine the subject of parental rights. The controversial right of the surrogate mother does not support the aims of surrogacy, which seeks to allow people suffering from infertility to become parents a child conceived using their genetic material. Judge G. Gadzhyev noted the considerable complexity in resolving the issue under discussion and, inter alia, emphasized the following:

1) the exclusive right of a surrogate mother obviously entails disputes about the child's destiny;

2) the legislation does not provide a definition of the concept of "the child's mother," making it unclear whether the surrogate mother is a mother in the sense in which the Russian Constitution provides protection to motherhood;

35 The wording is very mysterious with regards to family law, since de facto marriage does not have any legal status in Russia, and only spouses or unmarried persons (single ones!) are entitled to adopt a child... It is not difficult to build an analogy.

36 Since 1930s, Russian legislation has actively operated with the term of "single woman" (alternatively, "single mother"). The term of a "single man" has been unknown to it. Here, apparently, both the rhetorical question and philosophical reflection would be appropriate. 
3) from a medical point of view, the origin of a person is established by the identity of genes; legislation proceeds from the more significant fact of bearing and birth of a child, which is not indisputable.

In the meantime, the Supreme Court of the Russian Federation, in the Decision of 16 May 2017 No. 16 "On the Application of Legislation in Court in Cases Involving the Determination of the Origin of Children" (item 31), offered a completely different, non-standard opinion when considering a child born within surrogate motherhood program. It ruled that if the surrogate mother refused to consent to registration of the genetic parents, this could not be an unconditional basis to reject the genetic parents' claim to be recognized as the child's legal parents and allow them to raise the child; to consider the case properly, the court should check whether the surrogate motherhood contract was concluded, whether the plaintiffs are the genetic parents, the reasons behind the surrogate mother's refusal and, with reference to the provisions of Art. 3 of the Convention on the Rights of the Child, resolve the dispute in the child's best interests. This interpretation of the court's capabilities does not directly conform with the meaning of the provision in Art. 51, item 4, part 2 of the Family Code of the Russian Federation, and does not match the legal position of the Constitutional Court of the Russian Federation (although it responds to some of the doubts of its judges as recorded in their dissenting opinions). On the other hand, this flexibility, on a case-bycase basis, could indeed protect the best interests of the child. Obviously, courts are "allowed" to make decisions in favor of genetic parents. This interpretation, which, in its essence makes for a new legal standard, does not interfere with the authority of the Supreme Court, whose competence does not presuppose the creation of regulatory acts. That function is prescribed only to the Constitutional Court of the Russian Federation, which has the authority to recognize normative legal acts (legal provisions) as unconstitutional and, based on this, suspend them. We believe that, in order to correctly implement existing legislation and the legal position of the Constitutional Court (as the family legal norm above is imperative), an immediate change is needed in this part of the Family Code. This change would force Russia's legislators to reconsider their position on the priority of the rights of the surrogate mother, in favor of equal opportunities for the surrogate and genetic parents based on the fundamental idea of securing the best interests of the child within a judicial discretion.

It should be noted that foreign legislation is far from unanimous with regard to the legal regulation of relations within surrogate motherhood: in some countries, the program is prohibited ${ }^{37}$ or only available if pro bono provision conditions are met.

${ }^{37}$ Some Russian politicians speak in the same vein, believing that bearing of a child as a surrogate mother is a kind of human trafficking. France is among the countries that have banned surrogate motherhood. Judge Claire Legras, a member of the French Council of State, a member of the French national committee on bioethics (CCNE), states that the prohibition of surrogate motherhood is supported by the majority of French citizens. It is justified by ethical concerns about the child, the surrogate mother, and society as a whole. Claire Legras, Why Has France Banned Surrogate Motherhood? OUPblog, 23 February 2015 (Nov. 2, 2017), available at https://blog.oup.com/2015/02/france-surrogate- 
Elsewhere, it is available freely with no medical restrictions (it can even be possible due to the mother's need to schedule her babies around her career). At the same time, the priority parental rights can be assigned to the genetic parents, while the surrogate mother has the right to claim communication with the child in the best case (USA). The shift in emphasis in favor of clients is because assisted reproductive technologies tend to address the problem of infertility, and giving the advantage to the surrogate mother undermines this goal (as emphasized by judges of the Constitutional Court of the Russian Federation in their specific opinions).

It seems that there is no universal formula for a legislative solution: a surrogate mother may have a natural feeling of motherhood and refuse to yield the child to the genetic parents (the clients), which could be a major life trauma for them. In this respect, giving courts the opportunity to act at their own discretion and make fair decisions on a case-by-case basis, is more in line with the diversity of family relations and defends the "child's best interests." Nevertheless, as noted above, this must be recorded in legislation.

There are also conflicting laws about the child's ascension to legal capacity. Russian civil legislation states that minors under the age of 14 are "underage" and do not have the right to independently carry out any significant civil acts. Medical legislation calls for mandatory consideration of a minor's opinion from the age of 15. Legislation on education, inviting a child to primary school classes (usually at 7), inevitably provides him/her an opportunity to pursue the right to education (even if the parents' interests also considered in this case). When a child moves from primary to secondary education (at about 10 years old), he/she becomes subject to possible disciplinary responsibility, e.g. for the violation of the school code, failing to comply with internal regulations, etc. The Family Code recognizes a child's right to express an opinion on any important issue. ${ }^{38}$ Without setting any minimum age limit, it establishes a duty of parents, guardians and trustees, courts, etc. to take that opinion into account (if the court judgement differs from the child's wishes, the verdict has to be reasoned). It also rules that a number of family legal acts, such as changing the name, restoring the parental rights of biological parents, adoption, assigning a guardian, etc. can only be performed with the child's consent, if the child is 10

motherhood-ban/. Germany also legislatively banned surrogate motherhood under the threat of criminal liability (Embryo Protection Act (Embryonenschutzgesetz, BGBI. 1990 I S. 2746) and secs. 14b, $13 \mathrm{c}$ of the Adoption Placement Act (Adoptionsvermittlungsgesetz, BGBI 2002 I S. 354)). According to German law, therefore, the legal mother is always the woman who gave birth to the child. Under German law, artificial fertilisation as well as the mediation of a surrogate mother is a criminal offense (sec. 1591 of the German Civil Code). The strict prohibition of surrogate motherhood within these countries encourages citizens to enter agreements on surrogate motherhood and to have a child outside their borders, which generates further serious disputes before the European Court of Human Rights (Christian Kalin, Transnational Surrogacy in the Light of the Case-Law of the European Court of Human Rights, 10(6) Journal of Siberian Federal University. Humanities \& Social Sciences 906 (2017)).

38 Natalya Kravchuk, The Child's Right to Express His/Her Views in the Context of Russian Culture and Democracy, 2(3) Russian Law Journal 23, 34-35 (2014). 
or older (Art. 57 of the Family Code of the Russian Federation). We believe that the status of the child, as well as the gradual expansion of his/her legal capacity, should be systematized specifically in the Family Code. Moreover, it should be consistently specified in other branches of Russian legislation. This solution would be consistent with the spirit of the UN Convention on the Rights of the Child.

With regards to the nature of a child's legal status a question arises with no obvious answer in terms of jurisprudence: does the child have any inherent legal obligations? At first sight, the answer seems clear: yes, since children are under the care of their parents (or legally recognized mentors), they must obey that influence. However, in modern Russian legislation, including family law, we cannot find any direct instructions about children's obligations to anybody (as opposed to the imperial, pre-1917 law which stated that child was officially under the father's indisputable authority, and in his absence - under that of the mother or another guardian). According to lawyers, this is due to the legal incapacity of minors: because children are unable to fully comprehend the nature of their actions and control them, they should not incur any obligations, let alone be held accountable for them.

However, both the legal concept of the child's "floating" age-related capacity to act, and real-life practice, testify different things. Furthermore, as already noted, the legislator "lets the cat out of the bag" at times. For example, the provisions of Art. 43 of the Federal law "On Education in the Russian Federation" offer an extensive list of responsibilities for students, and item 4 of this provision stipulates their disciplinary responsibility for violating the charter of the educational organization or its internal regulations, etc. (these measures are not applied to preschool children and schoolchildren of lower grades, as indicated in item 5). If a child's written consent is required to appoint a specific guardian, etc. (Art. 57 of the Family Code of the Russian Federation), then, apparently, that child is obliged - in one form or another to express a legal position on the relevant issue. From the age of 14, as noted above, children already officially possess limited civil capacity and, as such, can bear liability under contracts, compensation for damage caused, etc. They may undertake duties as a spouse or parent (Art. 12, item 2, part 2, Art. 62 of the Family Code of the Russian Federation). In turn, part 1 of Art. 7 of the Federal law "On Basic Guarantees of the Rights of the Child in the Russian Federation" lists, among other competences of the public authorities (and not specifying the nature of the child's responsibilities), methodic and other activities to explain to children their rights and encourage them to fulfill their duties. Thus, one should not "bury one's head in the sand" and ignore the obvious.

Foreign legislation does not deny any of the child's responsibilities: Austrian, Bulgarian, Hungarian, Spanish, Italian law, etc., all include a provision on the children's respect for their parents. In Hungary, there is a prescription to follow their advice, while the U.S. (in some states), Italian and French law all require children to pay respect to parents; according to provision of Art. 1619 of the German Civil Code, children are obliged to provide any feasible help to parents within the household 
and in their activities; according to the laws of Finland, children from the age of 7 are obliged to study; and a provision in item 4 of Art. 124 of the Bulgarian Family Code stipulates that children should respect and help their parents and grandparents. Of course, children also have rights to protection against any abuse from parents and other caregivers (e.g. provision of item 2 of Art. 152 of the Family Code of Ukraine states: "children are entitled to stand up against improper performance of the parents' duties with regards to them").

The examples above cited are primarily declarative, as calls for due action. But the question is whether these declarations are a bad thing. In the Family Code of the Russian Federation, they are quite well presented: Art. 1 states the basic principles of family law, with respect and mutual support as the core principles; Art. 31 imposes duties upon spouses to build their marital relations based on mutual respect and mutual assistance, promoting well-being and strengthening the family. This plays a fundamental role in the legal regulation of family relations. Therefore, why do legislators in other countries, following the traditions of public life as well as actual practice, consider it necessary to call upon children to at least respect their parents and help in the family, while Russian legislators are silent here? Furthermore, as noted above, there is an actual contradiction when, for example, the law outlines the responsibilities of children in the field of education.

Thus, Russian children do have some responsibilities - these, however, are not positioned in a legally generalized form. The only thing left is to hope that children themselves are unaware of this legislative "indecisiveness." Even if they are aware, they probably understand that this is not entirely true.

Provision of Art. 57 of the Family Code of the Russian Federation states that, from the age of 14 , children are entitled to independent judicial protection of their family interests. However, this right is seemingly universal in its nature, as the provisions which specify those areas of law where a claim can be filed (such as establishing paternity, being deprived of or restricted in parental rights, etc.) do not allow for a child to be an independent subject. As for judicial practice, it often gives priority to the provisions of Art. 57: the conflict of laws is again overcome not by any improved legislation, but by the court taking a legal position beyond its competence.

Largely, the efficient legal protection of the rights and interests of children protection (and, indeed, the rights and interests of other subjects of family law) depends on the extent to which the judicial procedures envisaged by the law are "suitable" for considering various cases. Despite the obvious peculiarities of family cases involving minors in one form or another, Russia's currently operative civil procedural law does not offer any dedicated rules for their consideration. In this regard, for many years, legal scholars have offered opinions - with reference to historical and international experience - on how Russia's judicial system could be improved, as well as on procedural legislation about the participation of minors in the civil process. These fall into four areas: 
1) to create specialized (family or juvenile) courts;

2) to ensure that court structures are appropriately qualified;

3) to include in the Civil Procedure Code of the Russian Federation comprehensive provisions which regulate the specifics of court hearings involving minors;

4) to adopt the Code of Family Procedures.

To summarize the doctrinal outlooks on the urgency and expediency of the above concepts in the current conditions, we believe that the primary objective of the reform of civil proceedings regarding cases involving minors should be further development in two directions. In the legislative domain, we urge the inclusion into the Civil Procedure Code of the Russian Federation of an independent section devoted to the specifics of minors' participation in civil process; in the judiciary domain, we seek to ensure that duly qualified judicial assemblies exist at the level of district courts, at least while the idea of specialized family courts remains blocked by legislation.

It should be noted that, in some district courts, the use of specialist judges already occurs - as part of those courts within general jurisdiction as well as general rules of civil, administrative and criminal justice. However, in the first place, this specialization is rather conditional, and secondly, it does not presuppose the specialized training of judges in child psychology and other relevant branches of knowledge, nor any additional personal requirements for the judge (maturity in terms of age, life experience, judicial experience, etc.). At the same time, for quite some time the doctrine has actively supported the idea of introducing juvenile justice, with guardianship authorities as central figures. Legislators had discussed their respective proposals during a planning phase. However, widespread media coverage of cases of excessive interference into family affairs by some guardianship authorities in Scandinavian and other European countries, including cases when one of the parents held Russian citizenship, led to legislators taking a critical view of this idea and practice; the issue is now off the agenda.

Along with juvenile justice, in one form or another, the concept of specialist family courts has been introduced in Great Britain, Germany, Poland, the United States, Japan, etc. These courts follow separate procedures when considering cases, with an emphasis on conciliation between parties or agreement on a contentious issue, as well as the participation of psychologists and additional requirements on judicial staff, etc. Russian legislators have no comparable plans for the foreseeable future. In addition, there are no plans to introduce a compulsory procedure of mediation (based on certain foreign models). This idea is being thwarted, for both theoretical and economic reasons.

Recent practice has also faced the problem of same-sex parenthood. A common theme of discussions in Russia and abroad questions whether same-sex (in some countries - also multi-subject, e.g. three-parent) parenthood, adoption and guardianship is, in principle, aligned with the child's interests. At the same time, despite the absence of long-term and systematic monitoring over "LGBT educators" 
and participating children, there is a tendency in the western academic world to accelerate conclusions in favor of the unconventional family and a "witch hunt" over supporters of the traditional family. When a break from the norm is regarded as good, traditional norms are viewed as a brake to the overriding victory of tolerance. Thus, human rights are elevated to an absolute, in defiance of the child's rights. Meanwhile, some well-known Russian sociologists point out the obviously unnatural character of such an environment for a child, and homosexual parents themselves call the childhood years of such children "closeted": the child is in a stressful condition that even the flexible mentality of a junior cannot easily relieve. Thus, the principle of comprehensive care put forward by the Convention on the Rights of the Child explicitly conflicts with the egocentrism of gay parents of the child, whose sexual orientation is, in most cases, different from them; in addition, it is impossible to ignore the quite obvious observations of psychology and pedagogy on the child's imitation of adult behavior. Some foreign scholars do resist the Western tendency in question, claiming that the conclusions reached by successful relations reflect the malign influence of a specific group of educators. ${ }^{39}$

In general, Russian legislation has a negative attitude towards one-sex parenthood ${ }^{40}$ although this is very rarely declared directly. Thus, by the enactment of Art. 127, item 1, part 13 of the Family Code of the Russian Federation, the adoption of Russian children is forbidden to citizens who are in an alliance made between persons of the same sex, even if it is recognized as marriage and registered in accordance with the legislation of the state in which such marriage is permitted. In addition, adoption is not open to unmarried heterosexual couples. As, according to Russian family legislation, legal relations in adoption are equal to parental relations (item 1 of Art. 137 of the Family Code of the Russian Federation), this leads to a certain conclusion about the overall attitude of legislators. ${ }^{41}$ On the other hand, the lack of

In particular, the American professor Lynn Wardle has published her concerns about the ambiguity of the research into the influence of a child's upbringing in a homosexual family. There are a lot of questions and comments about existing research in terms of its methodology: a small number of control groups and samples, biased sampling, wrong methodological toolset, groundless scientific hypotheses, ambiguous conclusions (Lynn D. Wardle, The Inner Lives of Children in Lesbigay Adoption: Narratives and Other Concerns, 18 St. Thomas Law Review 511 (2005); Lynn D. Wardle, Comparative Perspectives on Adoption of Children by Cohabiting, Nonmarital Couples and Partners, 63 Arkansas Law Review 31, 86 (2010)). In terms of this problem, the results of a large-scale study conducted among young Americans might be of interest. The chosen methodology was able to confirm the negative impact on the child on a number of parameters of upbringing in a family where non-traditional sexual relations of parents was articulated. See for details Mark Regnerus, How Different are the Adult Children of Parents Who Have Same-Sex Relationships? Findings from the New Family Structures Study, 41(4) Social Science Research 752 (2012).

40 It should also be noted that political doctrine trends can restrict international adoption (see, e.g., the widely known "Dima Yakovlev Law"), and, possibly - complete rejection of it.

41 In one interview (in Oliver Stone's film), the Russian President demonstrated a sufficiently reasoned approach to the problem: children must first grow up in ordinary family circumstances, and upon reaching adulthood, have the right to make any decision about their life goals, including sexual orientation. 
legal consequences for a married parent undergoing a sex change can lead to singlesex parentage. Although there was a case when a father who became a female was deprived of parental rights, the sex change itself was not cited as the reason behind that decision. Instead, the parent's behavior (and his active and public demonstration of the new life circumstances) was regarded as having a demonstrable negative effect on the mental state of the child. With Russian legislation's obvious commitment to traditional family values, there is also no legal response to gender change in a situation of extramarital parentage. Therefore, it is clear that " $\mathrm{A}$ " is not necessarily followed by " $B$," and the laws are drawn without any logic or common sense.

Another noteworthy trend in Russian family legislation is the commercialization of guardianship. In most cases, this form of childcare is based on a reimbursable agreement between guardian or trustee agencies and candidates for custody. On the one hand, this state support can only be welcomed. However, on the other, there is far less support for extra-marital motherhood, and none at all for adoption. Clearly, this problem should also be assessed by Russian legislators in a more systematic way: material support should be provided not so much on the basis of differentiation of forms of childcare, but they should be targeted, depending on the life circumstances of the individual family with a child.

\section{Conclusion}

The status of this article does not allow us to fully identify all the trends in the evolution and development of Russian marriage and family legislation, together with its achievements and their rejection, its gaps and paradoxes. However, due to our reflections on this subject, despite their limited formal scope, we are entitled to formulate several assertions.

The 1917 decrees on marriage and family represented a vivid new revolution in legal regulation of family relations and their basic provisions are by no means exhausted. These, as well as the codes that followed them, fell to the counterrevolutionary strike of the regulatory and legal decisions of 1940s, which in terms of their principle positions threw Russian (Soviet) legislation back to the $19^{\text {th }}$ century.

The "Khrushchev thaw" was accompanied by a return to the principles stated in the first decrees and codes, but without protecting the socially significant interests of partners in de facto marriages.

Also, Russian (Soviet) family law had a tangible, but far from comprehensive impact on the legislation of Eastern European states (first of all, in gender equality, property regime in marriage and legal status of children). Here, sovereignty was to a large extent preserved due to marriage and family legislation being substantially predetermined by national culture and traditions, not always directly related to politics and economy. On some issues, the reverse happened: the legislation of these countries, on the contrary, provided information that helped Soviet and Russian 
civil law scholars to reflect on ways to improve domestic family and civil procedure legislation. The same can be said about the family and legal decisions of the former Soviet republics.

The key discourses of Russia's modern family law doctrine are the following problems:

1) systemization;

2) removal of inconsistencies around the status of children;

3) legal recognition for de facto marriage;

4) prevention of excessive freedom in marriage contracts;

5) optimization of the legal aspects of surrogate motherhood, in respect of childcare and the introduction of judicial specializations and extended judicial discretion in family cases;

6) elimination of conflicts between family and civil procedural legislation.

Among various background discourses, we find problems surrounding the legal acceptance of same-sex partnership and/or marriage, as well as same-sex parenthood.

Each of the stated objects to be considered by scientists, legislators, practicing lawyers and public figures has its own "road map," which generally assumes a tripartite nature - adherence to the progressive ideas of 1917, which established the sovereign branch of Russian family law; resistance to various "counterrevolutionary" impulses; and rapprochement with the doctrine and practices of European legislation - while preserving Russia's traditional family values. Whether this complex vector leads to an internal and external harmonization of the Russian family legislative positions will be clear during the decade following 2017.

\section{References}

After Legal Equality: Family, Sex, Kinship (R. Leckey (ed.), Abingdon, Oxon; New York, NY: Routledge, 2015).

Antokolskaia M. Harmonisation of Family Law in Europe: A Historical Perspective: A Tale of Two Millennia (Antwerp: Intersentia, 2006).

Barak A. Judicial Discretion (New Haven: Yale University Press, 1989).

Gray N. \& Brazil D. Blackstone's Guide to the Civil Partnership Act 2004 (Oxford: Oxford University Press, 2005).

Herring J. Family Law ( $3^{\text {rd }}$ ed., New York: Pearson Longman, 2007).

Johnson P. Marriage, Heteronormativity, and the European Court of Human Rights: A Reappraisal, 29(1) International Journal of Law, Policy and the Family 56 (2015).

Kalin C. Transnational Surrogacy in the Light of the Case-Law of the European Court of Human Rights, 10(6) Journal of Siberian Federal University. Humanities \& Social Sciences 906 (2017).

Kravchuk N. The Child's Right to Express His/Her Views in the Context of Russian Culture and Democracy, 2(3) Russian Law Journal 23 (2014). 
Maleshin D. The Russian Style of Civil Procedure, 21(2) Emory International Law Review 545 (2007).

Tarusina N. \& Isaeva E. Equalization of Legal Status with Respect to Gender, 4(3) Russian Law Journal 74 (2016).

Tarusina N. European Experience and National Traditions in Russian Family Law, 3(2) Russian Law Journal 97 (2015).

Wardle L.D. Comparative Perspectives on Adoption of Children by Cohabiting, Nonmarital Couples and Partners, 63 Arkansas Law Review 31 (2010).

Wardle L.D. The Inner Lives of Children in Lesbigay Adoption: Narratives and Other Concerns, 18 St. Thomas Law Review 511 (2005).

\section{Information about the authors}

Nadezhda Tarusina (Yaroslavl, Russia) - Professor, Head of the Social and Family Law Department, Dean of the Faculty of Law, Demidov Yaroslavl State University (10 Sovetskaya St., Yaroslavl, 150000, Russia; e-mail: nant@univ.uniyar.ac.ru).

Elena Isaeva (Yaroslavl, Russia) - Associate Professor, Faculty of Law, Demidov Yaroslavl State University (10 Sovetskaya St., Yaroslavl, 150000, Russia; e-mail: elenia2000@mail.ru). 